\title{
The impact of Non-Financial Incentives on employees' motivation
}

\author{
Muhammad Ijaz ${ }^{1}$, Azhar khan ${ }^{2}$ (supervisor) \\ Executive Development Center, Gandhara University, Peshawar, Pakistan
}

\begin{abstract}
The purpose of this study is to exhibit to what extent non-financial incentives are utilized in the public sector of Pakistan; Agricultural Training Institute (ATI) and whether non-financial incentives have the potential to increase the motivation of public employees as much as the financial incentives. Incentive is any means that makes an employee desire to do better, try harder and expend more energy. Non-financial incentives such as participation in decision making, verbal or written recognition of good work etc. are the kinds of incentives that do not involve direct payment of cash.

To realize the objectives of the thesis, a survey study was administered at Agriculture Training Institute. According to the results of the study, most of the employees think that the level of utilization of the nonfinancial incentives in their organization is inadequate. Also, the findings suggest that they value non-financial incentives as much as financial incentives. Thus, within the limitations of the survey study, it may be concluded that non-financial incentives have the potential to increase the motivation of personnel in this public organization.
\end{abstract}

Keywords: Non-financial Incentives, Motivation, Recognition, Public Organizations.

\section{Introduction}

It is widely accepted by organizational experts manpower is of the most valuable asset of every organization because work is carried out through human beings. The true success of an organization is dependent on employees. Organizational personnel can divert the direction of the organization from low profit to high profit and vice versa.

The purpose of this study focuses on non-financial incentives and their impact on employees' motivation. It also focuses how much non-financial incentives are applied/ practiced in public sector employees. As non-financial incentives do not involve direct payment of cash to employees. It may be tangible or intangible. Some examples of non-financial incentives includes; involvement of employees in decision making, recognition of employees on desirable performance, assigning tough but attainable assignments, appreciating work through small gifts like plagues, ticket to restaurant etc.

\section{1 purpose of the study}

The study will focus on the solution of problems and issues that are associated with the well administered compensation and its practices in public sector (Agriculture) Pakistan. As we know that agriculture is the back bone of Pakistan's economy and most of the people either directly or indirectly dependent on agricultural products. Therefore it is vital to develop this sector according to the present needs. In order to develop this sector, all the employees in the agriculture sector must be motivated to use their skills properly. I will focus the employees of Agricultural Training Institute, district Peshawar, Khyber Pakhtoonkhwa. All the employees of Agricultural Training Institute, Peshawar, are categorized in grade system like the head of Agricultural Training Institute is Principal who is placed in grade 20, Vice Principal BPS 19, all the immediate officers are placed in grade 18, 17, and up to 1 .

\subsection{Objectives of the study}

1.2.1 To find out the degree of utilization of the non-financial incentives in this public organization, based on the perceptions of public employees?

1.2.2 To know which type of non-financial incentive do the public employees value most?

1.2.3 To discover what type of incentive in this organization employee's value most?

\subsection{Incentives, rewards and recognition}

\section{Literature Review}

The term "incentives", "Rewards", and "Recognition" are used interrelated in the organization setting and there is no broader difference among them. However the main category is the incentives. Incentives mean any source or medium that encourages an employee or group of employees to perform better and to exert more effort beyond expectations. Basically incentives are divided into two main groups: Financial incentives and non 
financial incentives. Financial incentives include direct payment of cash and while non financial incentives may be in the form of promotion of employees, flexible time, autonomy and involvement in decision making etc.

\subsection{Motivation}

Motivation is something that can lead to better performance when other conditions are met (Ivancevich, \& Matteson 1988). The term "motivation" is derived from the word "motive" means any reason for taking action. The psychological processes that cause the arousal, direction and persistence of voluntary actions that are goal directed (Kreitner \& Kinicki et al.2004. A general definition for motivation can be given as "the degree to which an individual want and chooses to engage in certain specified behavior. Motivation in the work place refers to, the degree to which an individual wants and tries hard to do work well at particular task or job (Mitchell, 1982). According to Abraham Maslow (1943), employees have five levels of needs that motivate them to accomplish most of the levels. Levels of needs are: physiological, safety, social, esteem and selfactualization. If the organization has well administered compensation strategy, employees will be motivated to satisfy their needs. The job related factors (work itself-challenging, opportunity for advancement) are the real motivators and others are just Hygiene factors that retain employees in the job (Herzberg, Mousner \& Snyderman 1959). Job characteristics model pointed out that the jobs with non- financial incentives have a high motivating power (Hackman \& Oldham, 1980).

\subsection{Promotion}

Promotion can be used as motivational tool. It is a way of rewarding the employees meeting the organizational goals thus it serves as mean of synchronizing organizational goals with personal goals (Lazear \& Rosen, 1981).

\subsection{Employee Recognition}

It is crystal clear that the main and repeated cause of turnover is the lack of employees' recognition. In particular, this lack of recognition has resulted in firms loosing disenchanted innovators as well as lower level of effort and even sabotage and espionage (Dutton,1998). Disturbingly, recognition is often perceived as a costly, non essential practice and generates no significant benefit to organization (McConnell,1997). Gines (1998) observes that companies must foster employee motivation through acknowledging achievements that are in line with corporate long term objectives as well as activities that generate immediate results.

\subsection{Feedback}

Feedback is basic source of educating human in the sense of removing barriers they face in propagating their activities towards the targets they are given in their working environment (Watts, 2007).

\section{Theoretical Framework}

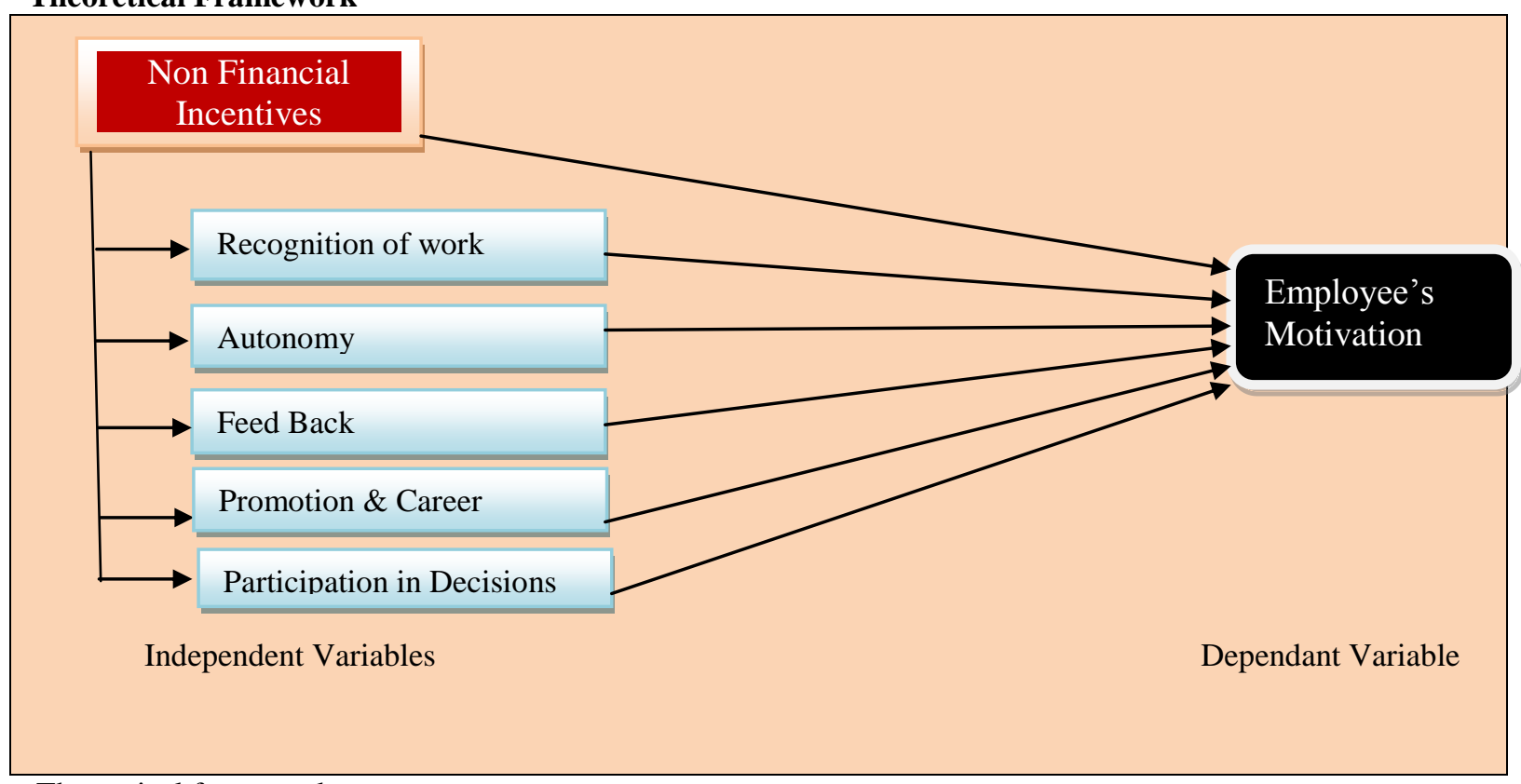

Theoretical framework 


\subsection{Data Collection}

\section{Research Methodology}

A questionnaire list has been used for the collection of data. The researcher had direct access to the Agricultural Training Institute for collecting the data. A copy of this questionnaire is included in appendix A.

\subsection{Study Population}

For the purpose of this study the employees of Agricultural Training Institute (ATI) were selected. The Agricultural Training Institute (ATI) has a total number of 100 employees. The main aim of this institute is to provide training to people/ students/ officers, who will be able to handle agricultural related problems in different areas of the province/ country. The list of questionnaire is distributed among all (100) employees. The researcher had fully access to all employees of Agricultural Training Institute (ATI), as being a resident of the same ATI colony. So due to easy access most of the employees participated and completed the questionnaire list. Some of them also refused in participating the study. However the response rate was $80 \%$.

\subsection{Demographic characteristics}

The demographic section of the questionnaire consists of age, gender, level of education, position level, number of years worked in organization, and the name of the department where an employee works. In the sample the number of male respondents are $\mathrm{N}=75(93.75 \%)$ while female respondents are $\mathrm{N}=5(6.25 \%)$. The majority of respondents are of age between $36 \& 45$. Majority of the employees (52\%) are master degree holder. Most of the employees are having non managerial jobs. Most of the employees have worked for more than 10 years in the current organization. The department of employees according to the nature of their jobs, some do job in finance, human resource, training and development department.

\subsection{Hypothesis}

Null Hypothesis (Ho)

Non- financial incentives have no impact on Employee's motivation.

Alternate Hypothesis (H1)

H1: Non-financial incentives have positive association with employee's motivation.

H1a: Promotion and career opportunities have positive impact on employees' motivation.

H1b: Participation in decision making has positive impact on employees' motivation.

H1c: Autonomy has direct positive impact on employees' motivation.

H1d: Recognition of employees for work has positive impact on employee's motivation

H1e: Feedback has direct positive impact on employees' motivation.

\section{Data Analysis}

In order to quantify the data of respondents, a common Likert-scale of five choices has been applied. The same data is also explained with a pie chart also. The entire questionnaire (from 8 to onward) is tabulated along with pie charts. In addition to this, the thesis hypotheses are also presented in the following table.

Q8. In general terms, how important are non financial incentives in influencing your willingness to exert more effort in your job.

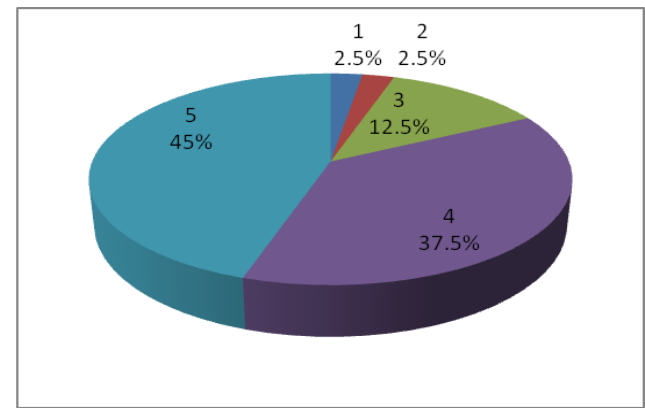

Fig 5.1

\begin{tabular}{|l|l|l|l|}
\hline N0 & Choices & Frequency & Percent \\
\hline 1 & Not all important & 2 & 2.5 \\
2 & Not very important & 2 & 2.5 \\
3 & Neutral & 10 & 12.5 \\
4 & Important & 30 & 37.5 \\
5 & Highly important & 36 & 45 \\
& & & \\
\hline & Total & 80 & 100 \\
\hline
\end{tabular}

Table 5.1

The figure shows that the majority of the respondents (45\%) were of the view that non financial incentives are very important in influencing willingness to exert more effort in the jobs. Also $37.5 \%$ of the respondents consider non financial incentives as having a positive influence on their motivation towards their job. This information illustrates that along with financial incentives non financial incentives also play significant role in nurturing willpower of employees. 
Q9. Job security motivates me to higher job performance.

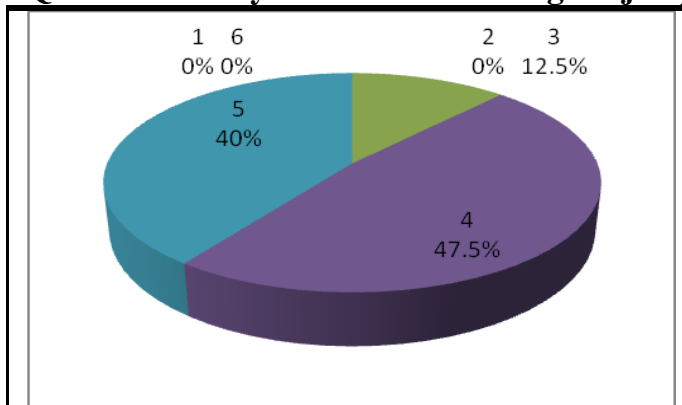

Fig 5.2

$\begin{array}{llll}\text { No } & \text { Choices } & \text { Frequency } & \text { Percent } \\ \mathbf{1} & \text { Highly } & 0 & 0 \\ 2 & \text { dissatisfied } & 0 & 0 \\ 3 & \text { Dissatisfied } & 10 & 12.5 \\ 4 & \text { Neutral } & 38 & 47.5 \\ 5 & \text { Satisfied } & 32 & 40 \\ & \text { Highly Satisfied } & & \\ & \text { Total } & \mathbf{8 0} & \mathbf{1 0 0}\end{array}$

Table 5.2

The figure shows the proportion of respondents who are motivated by the job security and hence lead to higher job performance. The majority of the respondents (48\%) followed by $40 \%$ were agreed that job security plays a vital role in the higher job performance. However, a very small proportion (12\%) of the respondents was neutral in their statements. Government employees enjoy their job security and it is also a great source of their motivation and good performance.

\section{Q10. A positive working environment is important for me to perform well in my job.}

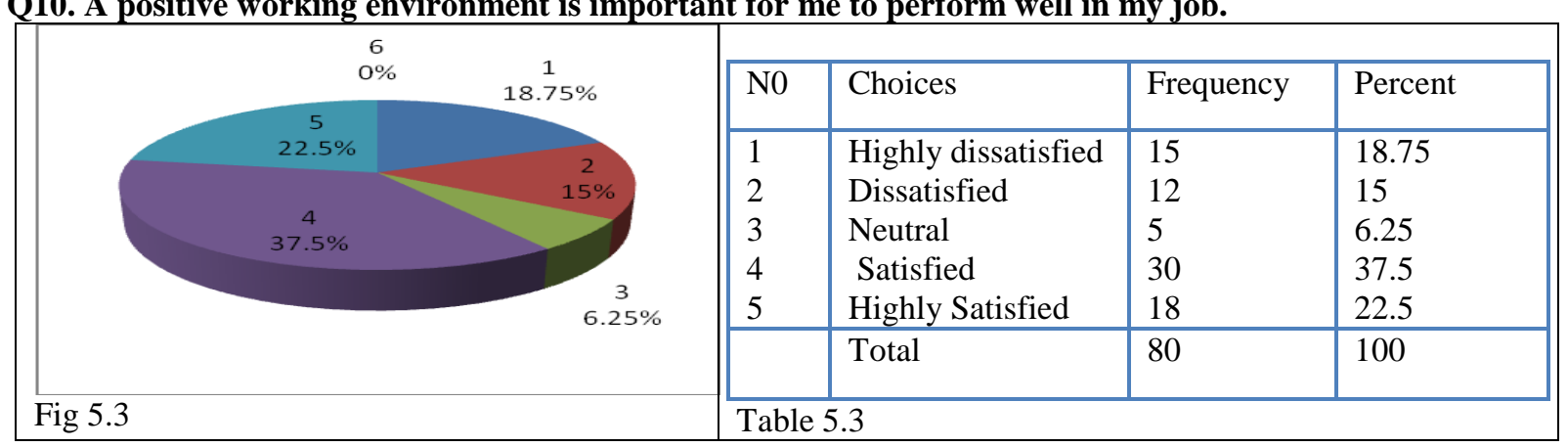

The respondents were asked to indicate whether the positive working environments important for good performance of their jobs. The results showed that $60 \%$ of the respondents were agreed that good environment plays a significant role and contribute to better performance of the employees. It includes peer to peer relationship as well as boss to subordinate relationship. A friendly environment is vital for deserved performance. However most of the respondents said indicated that that have excellent relationship with their peers and low or weak relationship with their superiors. Highly dissatisfied employees $18.75 \%$ pointed that though positive working environment is important for them, but it doesn't exist here in a sense of relationship between top management and lower management.

Q15.Gaining respect from others motivates me to do will.

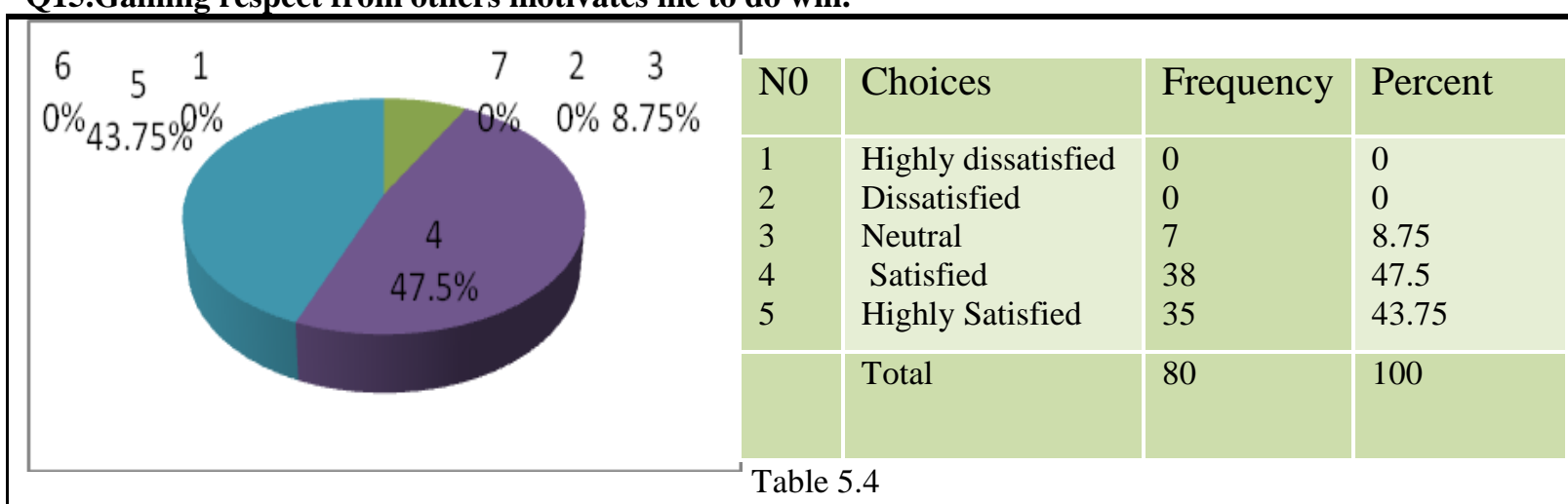

Fig 5.4

The results of the study depict that $47.5 \%$ of the respondent suggested they are receiving respects (in general terms)that lead to high motivation and the same statement is followed by $43.75 \%$ who have shown the high satisfaction with the statements. Most of the employees take care of each other inside or outside the organization. 
Q11. When I receive recognition, I am more motivated to perform better.

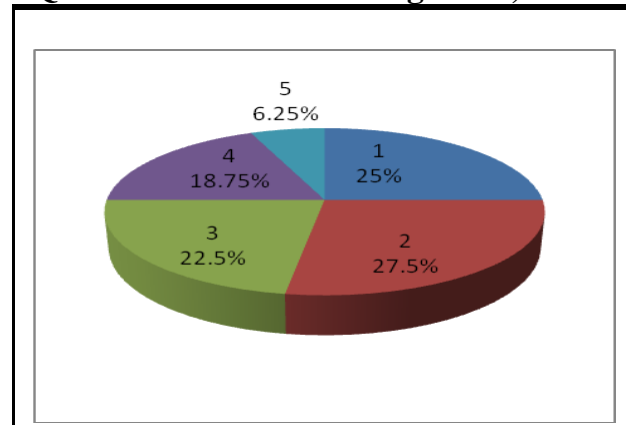

Fig 5.5

\begin{tabular}{|l|l|l|l|}
\hline N0 & Choices & Frequency & Percent \\
\hline 1 & Highly dissatisfied & 20 & 25 \\
2 & Dissatisfied & 22 & 27.5 \\
3 & Neutral & 18 & 22.5 \\
4 & Satisfied & 15 & 18.75 \\
5 & Highly Satisfied & 5 & 6.25 \\
& & & \\
& & & 100 \\
\hline & Total & 80 & \\
\hline
\end{tabular}

Table 5.5

The role of recognition in the motivation of employees that lead to the high job performance is unavoidable however; it is not appropriately practiced in the organization. The figure shows clearly that $52.5 \%$ of the employees are not receiving the recognition for their jobs and for their performance. $22.5 \%$ of the employees are neutral of their statements. Only $25 \%$ of the employees suggested that they are receiving some recognition for their attainments.

Q12. Rewards benefit will boost my motivation to work hard.

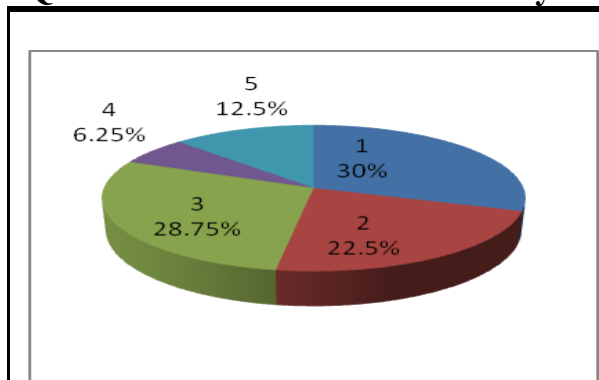

Fig 5.6

\begin{tabular}{|l|l|l|l|}
\hline N0 & Choices & Frequency & Percent \\
\hline 1 & Highly dissatisfied & 24 & 30 \\
2 & Dissatisfied & 18 & 22.5 \\
3 & Neutral & 23 & 28.75 \\
4 & Satisfied & 5 & 6.25 \\
5 & Highly Satisfied & 10 & 12.5 \\
\hline & & & \\
\hline
\end{tabular}

Table 5.6

The findings revealed that rewards are not used as this organization, as a source of motivation. Employees wish to receive non financial rewards for them but unfortunately they are not available in the organization for all employees who deserves. In the figure $30 \%$ of the employees are highly dissatisfied with rewards. $28.75 \%$ of the employees are neutral in their responses. Only $12.5 \%$ of the employees are highly satisfied and they are getting rewards for their high performance.

\section{Q13. If I am granted autonomy at work I will be more motivated.}

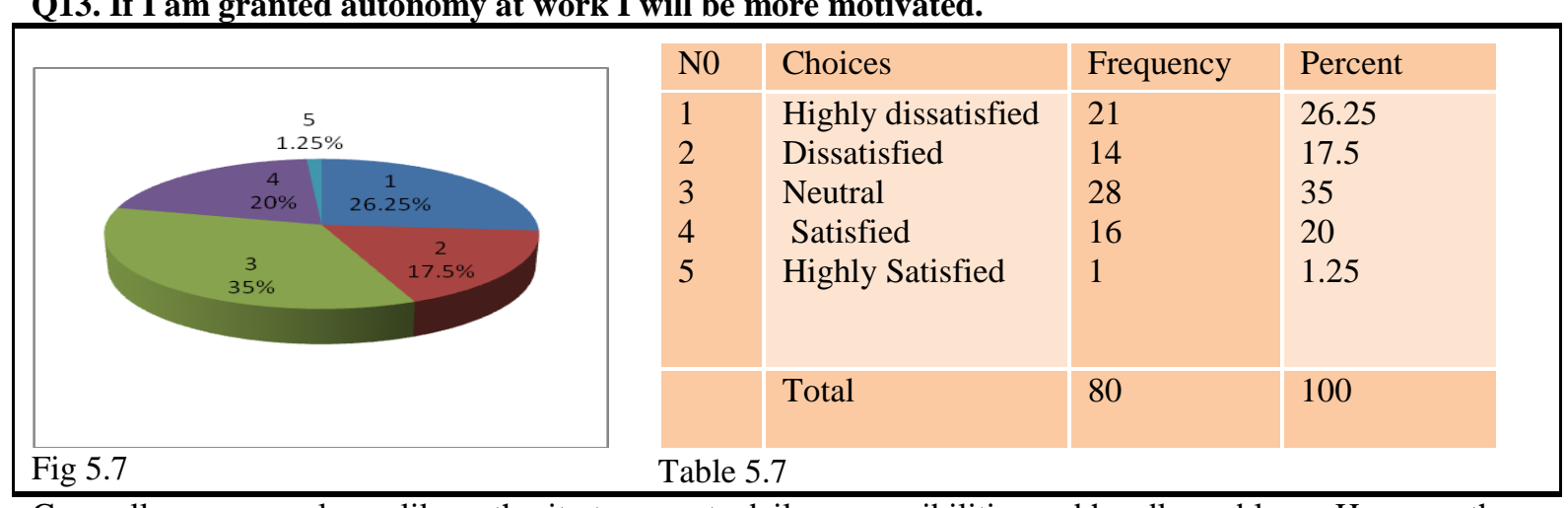

Generally every employee like authority to execute daily responsibilities and handle problems. However the figure reveals that there is centralization in the workplace. Employees have to take permission from the boss (principal).26. 25\% of the employees are highly dissatisfied and they don't have sufficient authority in the organization. $35 \%$ of the employees are neutral in their answers. While only $20 \%$ of the employees are happy with the autonomy and they are exercising it in the work place. 
Section 5: (Attributes of Non-Financial incentives)

Following are some of the job characteristics. Please indicate to what extent they are applied in your organization (a to $\mathrm{m}$ ).

c) Participation in decision making.

\begin{tabular}{|c|c|c|c|c|c|}
\hline $\begin{array}{cc} & 5 \\
4 & 11.25 \%\end{array}$ & & N0 & Choices & Frequency & Percent \\
\hline $13.75 \%$ & $\begin{array}{c}1 \\
32.5 \% \\
\\
2 \\
20 \%\end{array}$ & $\begin{array}{l}1 \\
2 \\
3 \\
4 \\
5\end{array}$ & $\begin{array}{l}\text { Not all Effective } \\
\text { Not very Effective } \\
\text { Neutral } \\
\text { Effective } \\
\text { Very Effective }\end{array}$ & $\begin{array}{l}26 \\
16 \\
18 \\
11 \\
9\end{array}$ & $\begin{array}{l}32.5 \\
20 \\
22.5 \\
13.75 \\
11.25\end{array}$ \\
\hline Fig 5.8 & & & Total & 80 & 100 \\
\hline
\end{tabular}

The respondents or employees like to participate in decision making process. It is a respect of an employee who is called to participate in decisions. However the organization doesn't give the opportunity to employees $(32.5 \%)$ to participate in issues and make a decision. However, $13.75 \%$ of the employees are satisfied and they are asked to participate in decisions. Here majority of the workers don't have participated in decisions. So taking part in decisions is a source of motivation and the management should do more efforts to ask maximum employees for participation in decision making process

e) Being recognized by superiors.

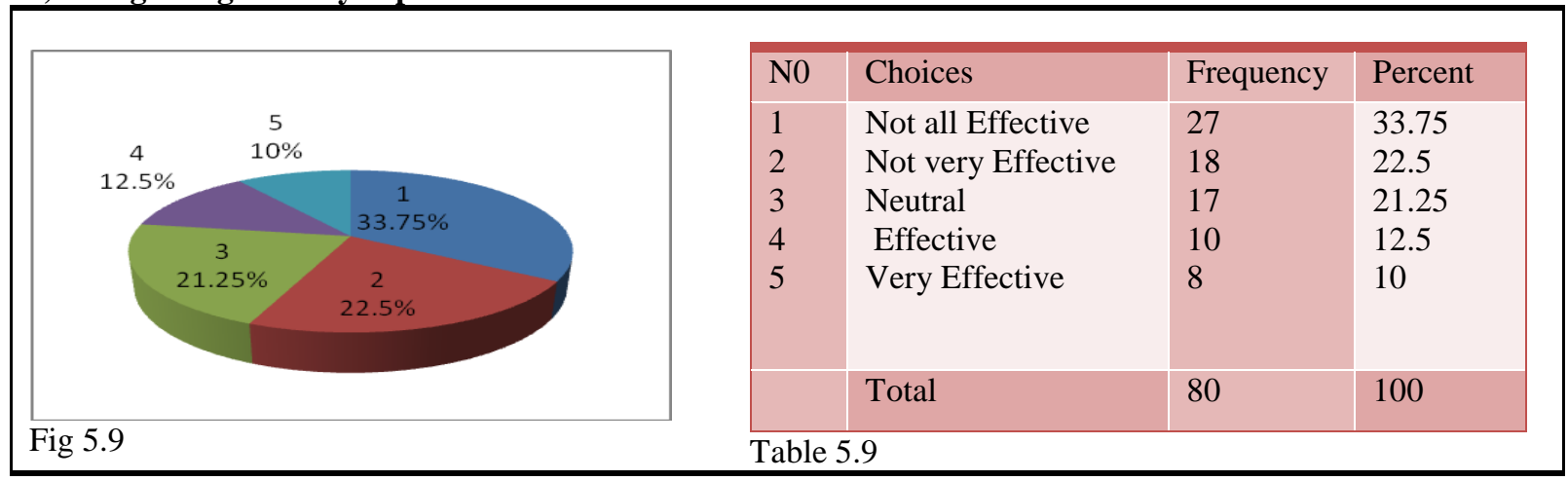

The Figure indicates that $33.75 \%$ of the respondents were not agreed with the statement. They are not recognized by the superiors or top management. However, recognition by the superiors is very effective in motivation towards good performance of the jobs.12.5\% of the employees were satisfied and suggested that it is effective and they are receiving it mostly informally.

g) Promotion and career growth in the company.

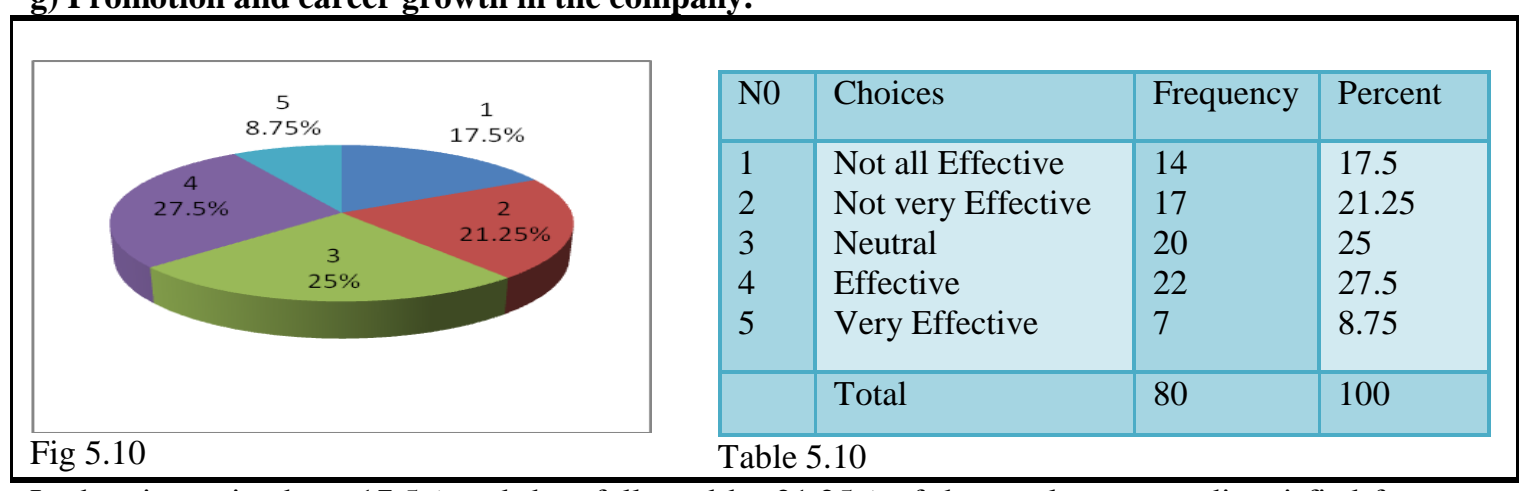

In the given pie chart, $17.5 \%$ and then followed by $21.25 \%$ of the employees are dissatisfied from promotion and career growth by the organization. However $27.5 \%$ of the employees are satisfied from promotion and their career growth. Mostly this figure justifies the political power of employees. Those employees are promoted who have sufficient power either inside or outside the organization. 
Training \& development as well as right evaluation system is needed in order to judge and promote employees. Due to promotion definitely employees will be motivated.

\section{k) Autonomy over daily schedule.}

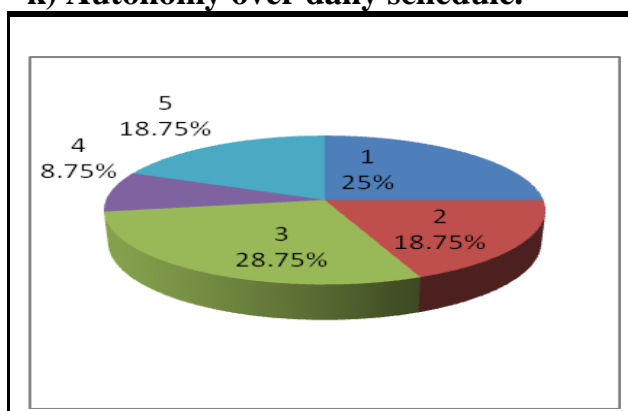

Fig 5.11

\begin{tabular}{|llll|}
\hline N0 & Choices & Frequency & Percent \\
\hline 1 & Not all Effective & 20 & 25 \\
2 & Not very Effective & 15 & 18.75 \\
3 & Neutral & 23 & 28.75 \\
4 & Effective & 7 & 8.75 \\
5 & Very Effective & 15 & 18.75 \\
& & & \\
\hline & Total & 80 & 100 \\
\hline
\end{tabular}

Table 5.11

Generally everybody likes to have autonomy over daily schedule. However it is not fully executed in this organization. $25 \%$ and followed by $18.75 \%$ of the employees don't have autonomy over daily schedule. However, those who are grade 17 and above or those who go for work that is outside the organization, have up to some extent autonomy over daily schedule $(18.75 \%)$.

m) Feedback from superior.

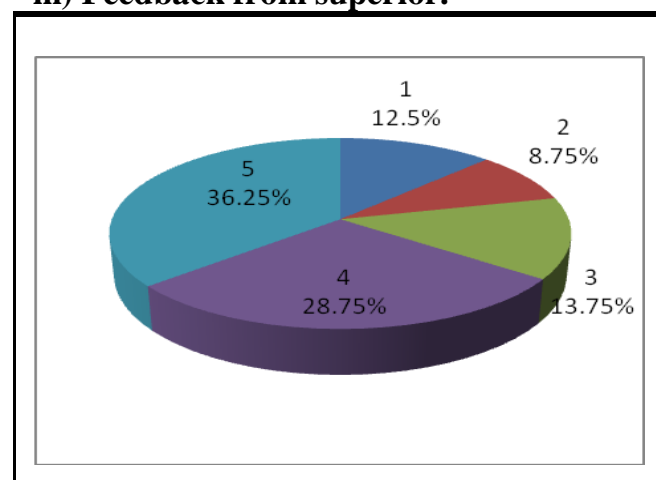

Fig 5.12

\begin{tabular}{|l|l|l|l|}
\hline N0 & Choices & Frequency & Percent \\
\hline 1 & Not all Effective & 10 & 12.5 \\
2 & Not very Effective & 7 & 8.75 \\
3 & Neutral & 11 & 13.75 \\
4 & Effective & 23 & 28.75 \\
5 & Very Effective & 29 & 36.25 \\
& & & \\
\hline & Total & 80 & 100 \\
\hline
\end{tabular}

Table 5.12

In the given pie chart $36.25 \%$ of the employees pointed that feedback from superior is very effective for motivation. Then it is followed by $28.75 \%$ of the employees, that feedback is effective for motivation. As most of the times powers are held by top management; so there is feedback between lower management and top management. As a whole there is a good feedback system in the organization.

Feedback shows how the progress is made and where corrective actions are needed in case of deficiencies. Mostly there is positive feedback as there is no complexity in work. There is traditional ways of doing things and employees are fully aware of that. However $12.5 \%$ of the employees pointed that they are not receiving feedback properly.

\section{Discussion}

Due to financial constraints, a non financial incentive is a best choice to motivate employees. Non financial incentives also cover many aspects of employees, such as social interaction in tours or in picnics, autonomy over daily schedule, flexible hours etc.

It is important for public organizations that employees should be publically recognized like in seminars and other social events where people get together. The organization should introduce newsletter system to recognize employees on daily basses if necessary. It is also important that an organization should have an adequate unit to judge the use and implementation of non financial incentives as well as to judge which incentives is mostly liked by employees. So accordingly the employees may get better than what they expect. In government organizations job rotation is not possible all the time however, job redesigning is possible and so the jobs should be periodically redesigned if necessary. The organization should give training to employees; it will add more knowledge, skills and abilities. Therefore training will provide a sound base for promotion and so automatically motivation will occur. Also it is necessary that government organizations should introduce flexible hours and finish this traditional timing i.e. from morning till evening. Timing should be flexible and the 
employees may select their working hours. Once flexible hours are introduced, employees will enjoy their daily life fully. They will happily perform their duties.

The organization should introduce interesting assignments. It will benefit the organization and employees. The organization will benefit in a sense that assignments or projects will complete on time; it will save other resources too. The employees will perform their duty on daily bases and none of the employee will be absent as because of interesting assignments. Moreover employees do not get bore even if they spent a number of hours on interesting tasks.

Employees should be acknowledged for the service of the organization. Those who serve the organization for several years, acknowledgement is must in order to motivate them further. Also the employees should be given autonomy over daily schedule. The employees should have autonomy to complete their duties happily. The centralization system wastes a lot of time for taking decisions. So this should be reduced and autonomy should be transferred to lower level management. The employees prefer to take more responsibilities along with autonomy. Responsibilities without necessary power are meaningless. An organization should have an adequate check \& balance system. There should be proper feedback mechanism regarding performance on daily or weekly bases. The organization should reward on good performance. In case of failure the management should investigate reasons and should take corrective actions.

\section{Conclusion \& Recommendations}

The analysis of the study highlighted many aspects of motivation. First of all non financial incentives are very important for motivation. It has been shown in (table 5.1), that majority i.e. $82.5 \%$ of the employees are motivated through non financial incentives in general terms. So its presence is crucial in the organization in order to motivate employees. In government sectors most of the employees feel and take precedence on private sectors' employees because of job security. From the analysis, (table 5.2) shows that $87.5 \%$ of the employees are motivated, because the employees are holding permanent jobs. Taking care of respect for seniors and juniors motivate employees too. Using ethical words and polite manner boosts employees' level of motivation. From the (table 5.8) majority, 91.25\% of the employees are motivated only through good interaction. For motivation a positive working environment is also important i.e. a relationship between managers and subordinates. About $60 \%$ (table 5.3) of the employees suggested that a positive working environment is very important for smooth operations. Only $25 \%$ of the employees suggested that they are receiving some recognition for their attainments. Recognition from boss is almost difficult. It is also interesting to note that $53.75 \%$ (table 5.5) of the workforce is motivated through adding more responsibilities. Everybody likes to have autonomy over daily schedule. However it is not fully executed in this organization. Table (5.11) shows that $27.5 \%$ of the employees don't have autonomy over daily schedule. Feedback from superior is sound strategy to motivate employees. Table 5.12 shows that $65 \%$ of the workers are motivated through feedback.

\subsection{Recommendations}

6.1.1. Recognition for motivation is very important. However low number of employees are receiving some sort of recognition, mostly from immediate colleagues. Therefore, whenever it is possible, the top management should recognize majority of the employees for their goal attainments. It is also important that the employees should be publically recognized, so the employees may assure, that they are the important part of the organization.

6.1.2. For true motivation autonomy at appropriate level is must. However, in this organization non managerial employees are more than officers. Therefore, all the operations will completed on time, powers should be transmitted to the lower management employees. It will help to accomplish a bridge between top management and lower management. About $43.75 \%$ of the employees don't have any authority. The organization is wasting time and resources because it takes time when decision comes from officers to the general workers.

6.1.3. Work itself / interesting assignment is a source of motivation. However due to rigid system, there is no concept of interesting task. Workers just follow orders of the top management. Therefore, whenever possible the managers should introduce interesting material in the task. It will remove boring as well as work will be completed on time. Workers will enjoy and will demand for new assignment. The project should be tough but attainable; the employees will apply all skills and will accomplish the project.

6.1.4. Participation of employees is must in decision making process. Working hours, wages, and other employee benefits should be developed at the presence of majority of employees. However in this organization 52.5\% employees are dissatisfied and they are not involved in decision making process. Involving employees in decision making will ensure the respect of employees; so it will definitely motivate employees. 
6.1.5. Promotion and career growth is too much important for motivation. Appropriate training and development as well as right evaluation system is needed for promotion. As most of the government sectors are under the political persons, so promoting the deserved employees in such environment is difficult. It is important that government sectors must be out of political pressures so that the competent employees may be promoted.

6.1.6. The concept of flexible working hours is must for motivation. As in this organization, there is no concept of flexible working hours due to the rigidity of the system. Workers follow that traditional timing i.e. from morning till evening. Once flexible hour's system is introduced in the organization, workers will select their own time table. So this will reduce the ratio of absent employees.

6.4 In the last but not the least, more researches are needed on non financial incentives in remote areas of Pakistan and should indentify which types of non financial incentives are valued most and what is their tendency toward non financial incentives. Also more researches should be conducted to identify the different preferences of non financial incentives in private and government organizations. More researches should be conducted on the implementation of non financial incentives in public sectors and its impacts on employment ratio.

\section{References}

[1]. Ivancevich, J., \& Matteson M. T. (1998).Organizational behavior and management. 5th ed. New York: McGraw-Hill.

[2]. Kreitner, R., \& A. Kinici. (2004).Organizational Behavior, 6th Editio n. Boston, MA: McGraw-Hill, Irwin.

[3]. Herzberg, F. (1966). Work and the nature of man. Cleveland: World Pub. Co.

[4]. Mitchell, J (1982). Looking after ourselves: an individual responsibility?. Journal of the Royal Society for Health, 4, pp.169-173.

[5]. Lazear, E. P., \& Sherwin R. (1981). Rank-order tournaments as optimum labor contracts.Journal of Political Economy.89, 841864.

[6]. Maslow, A. (1954) Motivation and Personality. New York: Harper Row.

[7]. McConnell, C.R, (1997), "Employee recognition: a little oil on the troubled waters of change", Health care supervisor, vol.15 No.4, pp.83-90.

[8]. Watts, S. A., (2007). Evaluative Feedback: Perspective on Media Effects, Journal of Computer Mediated Communication, 12, pp. 384-411.

\section{Appendix 1: Questionnaire}

\section{Section 1: Demographic Data}

Directions: Please select option that best describes you.

1. Gender

a.

Female b. Male

2. Age:

a. Less than 25 $25-35$ $36-45$ $46-55$ More than 55

3. What is your highest level of education?
a.
High School (O-level/A-level) Diploma
b. Bachelor's Degree Master 's Degree
c. M.Phil/M.S Doctorate

4. What is your position level?

a. operative $b$. Supervisor c. Manager

5. How long have you worked at your organization?

a. Less than 1 year $b$. 1-3 years $c$ 4-6 years d. 7-9 years e. More than 10 years

6. What department do you work in?

a. Finance b. Human Resource c Operation $\mathrm{f}$ IT $\mathrm{e}$ Management d. Accounts e. Other

\section{Section 2: Incentive}

7. What is the first word that comes to mind when you think about "incentive" 


\section{Section 3: Motivation}

Direction: In general terms, how important are non financial incentives in influencing your willingness to exert more effort in your job.

\begin{tabular}{|l|l|l|l|l|l|}
\hline & \multicolumn{1}{|c|}{$\begin{array}{l}\text { Not all } \\
\text { Important }\end{array}$} & $\begin{array}{l}\text { Not very } \\
\text { Important }\end{array}$ & $\begin{array}{l}\text { Neutral } \\
\text { Satisfied }\end{array}$ & $\begin{array}{l}\text { Highly } \\
\text { Important }\end{array}$ \\
\hline 8 & $\begin{array}{l}\text { How important are non-financial inventive in influencing } \\
\text { your willingness to exert more effort in your job? }\end{array}$ & & & \\
\hline
\end{tabular}

\section{Section 4: What motivates you? (attributes of motivation)}

Directions: Please indicate how strongly you agree or disagree with the statements and to what extent they are existed/ practiced in your organization.

\begin{tabular}{|l|l|l|l|l|l|l|}
\hline & & $\begin{array}{l}\text { Highly } \\
\text { Dissatisfied }\end{array}$ & Dissatisfied & Neutral & Satisfied & $\begin{array}{l}\text { Highly } \\
\text { Satisfied }\end{array}$ \\
\hline 9 & $\begin{array}{l}\text { Job Security motivates me to higher job } \\
\text { performance }\end{array}$ & & & & \\
\hline 10 & $\begin{array}{l}\text { A positive working environment is important } \\
\text { for me to perform well on my job. }\end{array}$ & & & & \\
\hline 11 & $\begin{array}{l}\text { When I receive recognition, I am more } \\
\text { motivated top perform better. }\end{array}$ & & & & & \\
\hline 12 & $\begin{array}{l}\text { Rewards benefit will boost my motivation to } \\
\text { work hard. }\end{array}$ & & & & & \\
\hline 13 & $\begin{array}{l}\text { If I am granted autonomy at work, I will be } \\
\text { motivated. }\end{array}$ & & & & & \\
\hline 14 & $\begin{array}{l}\text { If I get Flexibility in work, I will be } \\
\text { motivated. }\end{array}$ & & & & & \\
\hline 15 & $\begin{array}{l}\text { Gaining respect from others motivate me to } \\
\text { do well. }\end{array}$ & & & & & \\
\hline
\end{tabular}

Section 5: $\quad$ Following are some of the job characteristics(attributes of non financial incentives). Please indicate to what extent they are applied in your organization. (a To m).

\begin{tabular}{|c|c|c|c|c|c|c|}
\hline & Types of Recognition/ Reward & & of & en & & \\
\hline A & A personal "thank you" or note from my superior or colleague & 1 & 2 & 3 & 4 & 5 \\
\hline $\mathrm{B}$ & The opportunity to work on an interesting assignment /project & 1 & 2 & 3 & 4 & 5 \\
\hline $\mathrm{C}$ & Participation in decision making & 1 & 2 & 3 & 4 & 5 \\
\hline $\mathrm{D}$ & Acknowledgment for my years of service to the organization & 1 & 2 & 3 & 4 & 5 \\
\hline $\mathrm{E}$ & Being recognized by superiors & 1 & 2 & 3 & 4 & 5 \\
\hline $\mathrm{F}$ & Being recognized by peers & 1 & 2 & 3 & 4 & 5 \\
\hline G & Promotion and career growth in the company & 1 & 2 & 3 & 4 & 5 \\
\hline $\mathrm{H}$ & An award, certificate or anything to recognize my achievements & 1 & 2 & 3 & 4 & 5 \\
\hline I & Flexible working hours & 1 & 2 & 3 & 4 & 5 \\
\hline $\mathrm{J}$ & Small personal gifts like watches, pins, decorative, plaques, diaries etc) & 1 & 2 & 3 & 4 & 5 \\
\hline $\mathrm{K}$ & Autonomy over daily work schedule & 1 & 2 & 3 & 4 & 5 \\
\hline $\mathrm{L}$ & Increase responsibilities within current job & 1 & 2 & 3 & 4 & 5 \\
\hline $\mathrm{M}$ & Feedback from superior & 1 & 2 & 3 & 4 & 5 \\
\hline
\end{tabular}

